\title{
Transport Pollution: A Research of the Nigerian Transport Sector
}

\author{
Odogun, A., Georgakis, P.
}

\begin{abstract}
The growth in transport, especially road-based transport, is associated with environmental problems. Emissions from automobiles have been recognized as the main source of environmental pollution. The Nigerian population perceives road transportation as one of the primary environmental intruders. However, this problem has been substantially reduced in many developed countries as a result of the introduction of various technologies, including the local traffic reduction measures as well as the three-way catalyst. Inadequate transport infrastructure to support the increased number of vehicles plying the Nigerian roads has become a challenge to the government and the transport industry. This paper aims at providing contextual information on the environmental and health related to air pollution stemming from road transportation in Nigeria. Besides, it reviews the causes of transport emissions and the need for an integrated transport system in Nigeria.
\end{abstract}

Keywords: air pollution, environment, Nigeria, transport

\section{INTRODUCTION}

In any country, transportation is one of the main drivers of economic growth. However, the growth of road transportation has been linked to environmental issues. One of the common modes of transportation in Nigeria as well as other developing countries is road-based transport. Other modes of transportation include sea, air, and railway. As economies are growing, so also are the transport activities. The WHO (2012) claims that some of the pressing issues associated with road transportation include crude oil dependence, air pollution, as well as traffic injuries and fatalities. The emissions from the vehicles are the main sources of greenhouse gases (GHG), particularly in urban settings.

According to WHO (2012) report, ambient air pollution contributes to approximately 3.7 million premature deaths. Besides, the high rate of pollution in urban areas exposes residents to highs risks for birth complications, cancer as well as respiratory and cardiovascular diseases, which in turn are linked to increased death rates.

International Energy Agency (2016) claims that transportation contributed $23 \%$ of the overall carbon IV dioxide emissions from fuel combustions globally in 2014, and road transportation contributed 20\%. Santos (2017) states that the considerable reductions of GHG emissions have been hindered by the expensive transportation related to clean technologies and partial international treaties. Statistics indicate that at least $80 \%$ of urban residents are

Revised Manuscript Received on September 10, 2019.

Augustine Odogun, Faculty of Science and Engineering, University of Wolverhampton, United Kingdom.

(Email: A.Odogun@wlv.ac.uk)

Panos Georgakis, Faculty of Science and Engineering, University of Wolverhampton, United Kingdom.

(Email: P.Georgakis@wlv.ac.uk) exposed to air whose quality levels are way below the recommended WHO limits. Despite this being a global phenomenon, the population from low-income are severely affected. This is evident for statistics that indicate the air quality of about $98 \%$ of cities in the middle- and lowincome nations exceeding 100,000 residents fail to meet air quality guidelines as outlined by WHO. This percentage reduces to almost half in high-income nations where the air quality hits $56 \%$ mark. The major environmental hazard causing at least 3 million premature deaths globally every year is the ambient air pollution, which is highly concentrated with fine and small particulate matter.

A WHO report claims that it is crucial for the metropolitan and state governments to ensure that the air quality of metropolitan areas is a development and health priority since the improvement in air quality translates to minimal health costs associated with air pollution diseases, improved employees' productivity, an improved life expectancy. Besides, reduction in air pollution is significant in the reduction of adverse effects related to climate change, which can be a part of how committed nations are towards climate treaty. Electrification of public vehicles; changing petroleum fuel vehicle to fuel cell technology, keeping cars in top conditions, good road maintenance culture, walking or biking instead of driving and putting more electric cars on the road are among the suite of available strategies that would help to minimize road transport pollution in Nigeria.

This paper, therefore, aims to review the effect of transport emissions on the environment and suggest ways of reducing them to create a cleaner sustainable environment.

In this paper, a review of the Nigerian transportation industry is presented, and the need for an integrated transport system is defined. Furthermore, the paper discusses the problems associated with road transportation in Nigeria and how they contribute to air pollution. Finally, a way for the mitigation of the identified problems is discussed.

\section{BACKGROUND OF THE NIGERIAN TRANSPORT SECTOR}

Since the colonial period, the modern Nigerian transport has evolved tremendously. The colonial road, water, and rail networks were primarily constructed to facilitate the exportation of various cash crops produced locally as well as the importation of ready-made goods. However, reorientation goals came into being after the post-colonial

Published By: 
period where transport turned into a tool of the union in Nigeria and a significant instrument of socio-economic development. Besides, the exploitation and exploration of naturally occurring resources such as crude oil increased the demand for the transportation system. Evaluation of the quality and extent of the road network is imperative based years, the Nigerian government has achieved major milestones towards extending and improving the road network system.

However, the state of Nigerian transport infrastructure is in a miserable state and falls short of the comparable nations. As such, it is inadequate to meet the transformation agenda of the present administration as an instrument for realizing enhanced economic expansion and development. In addressing the infrastructural deficit, one of the challenges developing nations face is how to tackle major transportation problems such as increased personal cars on transportation, traffic accidents, congestion, and pollution.

According to the World Bank (2015), Nigeria's population is estimated to be more than 180 million persons, and an average annual population growth rate of about $2.6 \%$. Besides, Nigeria faces these transportation challenges, especially as it works towards building sustainable infrastructure for sustainable development.

\section{THE NEED FOR INTEGRATED TRANSPORT SYSTEM IN NIGERIA}

The Nigerian transportation system consists of different services and modes, including air, coastal shipping, inland water, road, and railway transport. Out of all these modes of transportation, road transport is the dominant form of transport in Nigeria. Potter and Skinner (2000) argue that the idea of an integrated transportation system has turned into a crucial controlling principle for structural and institutional development of transport policies in various countries.

Heated debates have sparked regarding the significance of reducing the environmental impact inherent to the Nigerian transport sector. As such, the development of an integrated transportation system is necessary to build up a regionally balanced, safe, sustainable, and efficient transport system. Potter and Skinner (2000) further suggest that sustainability can be improved by only developing advanced integrated strategies. Separate modes of transportation should operate in their field of usefulness and economy, with nondiscriminatory and competitive prices that are enough to support the advanced expansion of transportation infrastructure and services (European Commission, 2011).

This move would significantly facilitate economic efficiencies and comparative advantages to be suitably replicated on the operator costs. Dependability and sufficiency of transportation infrastructure and services are crucial for the country in attracting foreign direct investment as well as improving its competency in the international trade arena. As such, the government plays a significant role in this domain. Efficiency in transportation network is important in liberalized setup since it enhances the competitive efficiency as well as improve the productivity on road travel. Igwe et al. (2013) state that in the last fifteen roads, poor road networks, poor quality public of the economy in the global market. Besides, the transport

system is imperative in fostering the growth of regressive regions and subsequently integrating them with the mainstream economy by making them open to investment and trade.

\section{ROAD TRANSPORT AND CAUSES OF AIR POLLUTION IN NIGERIA}

The chief contributor to air pollution is road transportation, which is detrimental to environmental and human health. Akinola et al. (2014) state that emissions from vehicles contain several pollutants, including particulate matter and nitrogen oxides (NOx). NOx incorporates two other pollutants including nitrogen (IV) oxide (NO2), and nitric (II) oxide (NO). In the presence of the atmospheric air, the NO is readily converted into NO2 which on the other hand, reacts with the atmospheric air to form Ozone (O3) and nitrate particles. NO2 is a lethal gas to human beings when inhaled. On the other hand, NOx emissions are the main causative agent of eutrophication and acidification, thereby causing detrimental damage to the entire ecosystem. Transport \& Environment (2019) claims that road transportation contributes a third of the NOx emissions and metropolitan areas are the dominant source of this pollution due to heavy traffic.

Table- I: GHG emissions (GgCO2-eq) for Transport category in Nigeria. Source: (BUR1, 2018).

\begin{tabular}{|l|l|l|l|l|}
\hline Category & $\mathrm{CO}_{2}$ & $\mathrm{CH}_{4}$ & $\mathrm{~N}_{2} \mathrm{O}$ & Total \\
\hline Transport & 35239.57 & 308.57 & 474.21 & 36022.35 \\
\hline $\begin{array}{l}\text { Civil } \\
\text { Aviation }\end{array}$ & 98.22 & 0.01 & 0.84 & 99.07 \\
\hline $\begin{array}{l}\text { Domestic } \\
\text { Aviation }\end{array}$ & 98.22 & 0.01 & 0.84 & 99.07 \\
\hline $\begin{array}{l}\text { Road } \\
\text { transport }\end{array}$ & 33565.16 & 305.47 & 451.92 & 34322.55 \\
\hline Cars & 21369.09 & 212.42 & 306.19 & 21887.70 \\
\hline $\begin{array}{l}\text { Light-duty } \\
\text { trucks }\end{array}$ & 6571.09 & 65.72 & 94.05 & 6731.33 \\
\hline $\begin{array}{l}\text { Heavy-duty } \\
\text { trucks and } \\
\text { buses }\end{array}$ & 3370.64 & 4.80 & 19.41 & 3394.85 \\
\hline Motorcycles & 2253.86 & 22.54 & 32.27 & 2308.67 \\
\hline Railways & 73.60 & 0.09 & 8.80 & 82.49 \\
\hline $\begin{array}{l}\text { Water-bom } \\
\text { e } \\
\text { Navigation }\end{array}$ & 1502.59 & 3.00 & 12.65 & 1518.24 \\
\hline $\begin{array}{l}\text { Domestic } \\
\text { water-bome } \\
\text { Navigation }\end{array}$ & 1502.59 & 3.00 & 12.65 & 1518.24 \\
\hline
\end{tabular}

Although developed countries have a higher percentage of personal vehicle ownership compared to developing countries, air pollution and traffic congestion are worse in developing countries. Globally, the emission of carbon and the usage of energy are progressing at a faster rate in the transport industry, and transport emissions are progressing fastest compared to all in the developing nations. The

Published By:
Blue Eyes Intelligence Engineering \& Sciences Publication 
principal cause is rapid motorization, which has led to more cars and trucks on the road (Daniel and Deborah, 2002).

Rapid motorization demands for more road space as well as the expansion of energy use, thereby transforming people's lifestyle in negative and positive ways and much higher stress on the environment. The main challenge facing Nigeria and other developing countries is the formulation of strategies capable of increasing the mobility for a wide range of segments of the population at a cost-effective price devoid of triggering detrimental environmental issues. Exploration of alternative futures and strategic paths is crucial for the developing world to break the connection between GHG and economic growth (Daniel and Deborah, 2002).

\section{PROBLEMS OF ROAD TRANSPORTATION IN NIGERIA}

\section{A. Poor Road Infrastructure}

Some of the identified causes according to (Okigbo, 2012) for the poor state of roads in Nigeria include heavy traffic that exceeds the maximum permissible for the roads; lack of proper supervisory procedures for the roads; poor workmanship; use of poor quality construction materials; poor maintenance of the existing highways; and poor design and construction of the roads. According to the United Nations Development Programme (UNDP), the Nigerian road transportation networks is one of the lethal and poorest transport infrastructural system globally (Agbigbe, 2016).

Besides, the World Bank and UNDP claim that Nigeria had infrastructural deficits, particularly in transport industry, thereby making Nigeria one of the nations with the lowest economic development index in the past ten years. During rainy season traveling is difficult and sometimes impossible as a result of eroded road surfaces, potholes, and uneven road surfaces. Furthermore, most roads are normally covered with water due to lack of proper drainage system.

\section{B. $\quad$ Road Congestion due to Rapid Urbanization and} Overpopulation

As a result of population growth, (Filani, 2000) in (Adedeji, 2014) observes that the current rapidly increasing and a high number of socio-economic problems emanates from high rate of urbanization as well as rapid population growth rate. These problems are common during the physical planning of metropolitan cities, including Lagos that experiences traffic congestion in relation to places of intensive land usage activities such as Ikorodu Road. Besides, overpopulation and rapid urbanization translate to more cars on the road, which has resulted in continued congestion daily, particularly on major Nigerian networks.

\section{Accidents}

Road accidents, as well as traffic congestion, are two key external costs of transportation; hence, the policy makers aims at plummeting their effects (Wang et al., 2009). In Nigeria today, the rate of road fatalities is high. According to Agbonkhese et al. (2013), road carnage are a recurrent phenomenon in Nigeria, which makes Nigeria the second highest rated nation with the highest number of road accidents among the 193 ranked nation. The World Health Organisation (WHO) reports that over 1 million people die annually from road accidents with Africa having the highest fatality rates. Majority of the Nigerian vehicular accidents result from human and road factors. The road factors include road congestion, traffic jam, ongoing sites of repair or abandoned sites, and bad roads. On the other hand, the human factors include inpatient and ill-tempered drivers, flouting of road signs and traffic lights, and reckless driving.

\section{Lack of Other Means of Transport Especially} Railway Transport

Railway transport is the main intercity transportation system in most of the developing countries. On the other hand, developed nations have an underground railway transportation system referred to as subways in major cities. Such advanced railway transportation system minimizes the demand for road transportation. Besides, in developed countries, most of the heavy loads are transported through rail transport. This minimizes the load on the road transport system and the dangers posed by heavy trucks commonly seen in Nigerian highways. If only Nigeria had enough railway transport system, this would significantly reduce the congestion on roads, fatalities, and demand seen every day on Nigerian roads.

Fig. 1 Passengers hanging on a moving train in Lagos at Ikeja railway station. Source: (vanguard newspaper, August 2014)

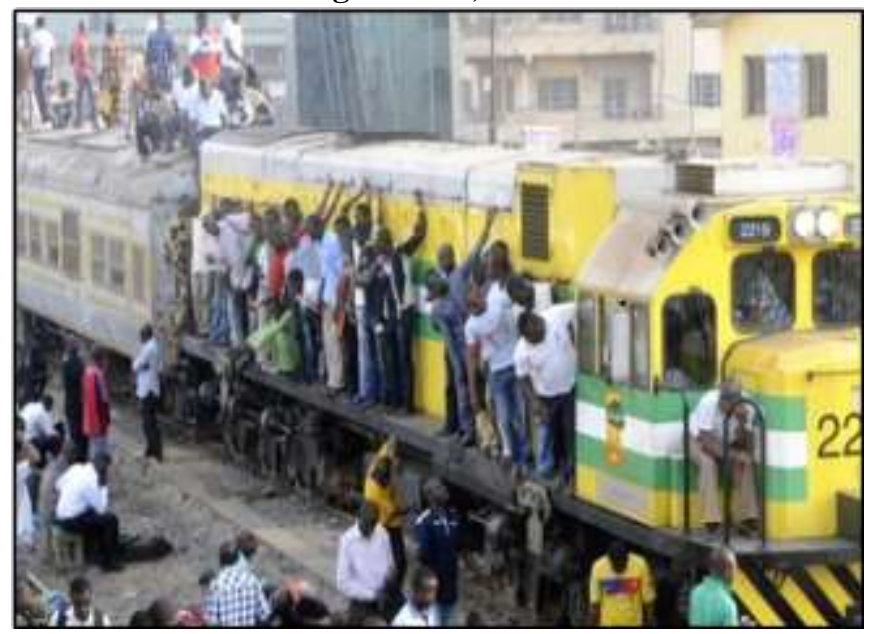

\section{ENVIRONMENTAL IMPACT OF ROAD TRANSPORT POLLUTION \& RESULTS}

\section{A. Health Implications}

Although transportation system is part and parcel of the contemporary life, WHO European Region face challenges related to the reduction of environment and health risks as well as meeting the requirements of nations for efficient transportation systems (WHO, 2005; Krzyzanowski et al., 2005). Air pollution exposes humans to silent killer diseases such as stroke, lung cancer, asthma, chronic and acute respiratory diseases, to mention a few (WHO, 2012).

Unfortunately, approximately $94 \%$ of the Nigerians are susceptible to air pollution, including PM. The PM can be 
suspended in air over an elongated period and travel over long distances, causing a variety of diseases that significantly reduces the life expectancy of the entire population (Kim et al., 2015).

\section{B. Environmental Pollution}

Noise and air pollution are two main environmental pollutants in the Nigerian road transportation system. Air pollution comprises nitrogen, lead, hydrocarbons, and carbon II oxide emission from the car exhaust pipes. These gases pose a great health hazard to the quality of life led as well as the health of both the community and motorists. The air pollution caused by traffic also has negative effects on the built environment. Metal corrosion and deterioration of coatings, lime, mortar, and construction elements through the action of acidic deposit of NOx and SO2 and particulate matter represent some of the current challenges. Complementary, soil contamination with chemical compounds from transport activities contribute to soil erosion, as the pollutants lead to the destruction of existing vegetation and soil organisms (Mihaela et al., 2018).

Table- II: Potential detrimental effects of the main automobiles exhaust pollutants on health and environment. Source: (Orisaleye et al., 2018)

\begin{tabular}{|c|c|c|}
\hline Pollutant & Health Effect & $\begin{array}{l}\text { Environmental } \\
\text { effect }\end{array}$ \\
\hline $\begin{array}{l}\text { Carbon } \\
\text { monoxide } \\
\text { (CO) }\end{array}$ & $\begin{array}{l}\text { Impaiment of } \\
\text { neuro-behavioral } \\
\text { function and } \\
\text { concentration. } \\
\text { Asphyxia lea ding to } \\
\text { heart and nervous } \\
\text { system damage. It is } \\
\text { lethal at high doses }\end{array}$ & $\begin{array}{lr}\text { GHG } & \text { causing } \\
\text { climate } & \text { change } \\
\text { or } & \text { global } \\
\text { waming } & \end{array}$ \\
\hline Ozone $\left(\mathrm{O}_{3}\right)$ & $\begin{array}{l}\text { Eyes and respiratory } \\
\text { tract irntations. } \\
\text { Heightens the } \\
\text { sensitivity respiratory } \\
\text { tract to allergic } \\
\text { triggers, particularly } \\
\text { in people who have } \\
\text { asthma. May intensify } \\
\text { vulnerability to } \\
\text { infections. }\end{array}$ & $\begin{array}{l}\text { Qxidants mmmto } \\
\text { plants impairs. } \\
\text { maturation as } \\
\text { well as growth. }\end{array}$ \\
\hline $\begin{array}{l}\text { Sulfur oxides } \\
\text { (SOx) }\end{array}$ & $\begin{array}{l}\text { Bronchoconstriction, } \\
\text { chronic bronchitis, } \\
\text { chronic obstructive } \\
\text { lung disease. }\end{array}$ & Acid rain, Haze \\
\hline Nitrogen & Worsen asthma, & Acid rain, Haze \\
\hline
\end{tabular}

\begin{tabular}{|l|l|l|}
\hline oxides (NOx) & $\begin{array}{l}\text { airway injury, } \\
\text { pulmonary oedema, } \\
\text { impaired lung } \\
\text { defenses }\end{array}$ & $\begin{array}{l}\text { Eutrophication is } \\
\text { leading to } \\
\text { alterations of the } \\
\text { aquatic } \\
\text { ecosystem. } \\
\text { Ground level } \\
\text { ozone precursor. }\end{array}$ \\
\hline $\begin{array}{l}\text { Hydrocarbons } \\
\text { (HC) }\end{array}$ & $\begin{array}{l}\text { Drowsiness, } \\
\text { coughing, and eye } \\
\text { imitations due to the } \\
\text { low molecular weight } \\
\text { compounds. The high } \\
\text { molecular compound } \\
\text { can be carcinogenic } \\
\text { or mutagenic }\end{array}$ & $\begin{array}{l}\text { Contribution to } \\
\text { the formation of } \\
\text { the Ozone layer, } \\
\text { pungent smell } \\
\text { and some direct } \\
\text { effects on plants, } \\
\text { and buildings. }\end{array}$ \\
\hline Lead(Pb) & $\begin{array}{l}\text { Impaiment of the } \\
\text { normalleaming } \\
\text { ability and } \\
\text { intellectual growth } \\
\text { and children. }\end{array}$ & $\begin{array}{l}\text { Particles in air } \\
\text { and groundwater } \\
\text { pollution }\end{array}$ \\
\hline
\end{tabular}

\section{WAYS TO REDUCE TRANSPORT EMISSIONS IN NIGERIA}

Road transportation emissions can be significantly reduced through the introduction of advanced technology such as measures geared towards reduction of local traffic as well as three-way catalysts, commonly used in European metropolitan cities (Colvile et al., 2001). In eastern Europe and developing countries, however, there is still the potential of high increase in vehicle ownership and use, which poses challenges as to whether these nations will adopt the preventive measures geared toward the reduction of air transport pollutants. The following measures would help to reduce transport emissions in Nigeria

\section{A. Electrification of Public Vehicles}

Introduction of hybrid buses for mass transit can significantly reduce transport system related emissions. In the United Kingdom, there are about 1200 electric-diesel hybrid buses which reduces the consumption of fuel as well as the emissions by approximately $40 \%$. Introduction of such buses in Nigeria will minimize the overdependence of diesel buses (David et al.; 2016).

In Lagos and many other big cities in Nigeria, most public journeys are made by buses using diesel and emissions from these buses are increasing daily because of the increase in the population.

\section{B. Technology}

Advanced technology such as catalytic converters can be used to minimize pollutant emissions such as $\mathrm{HCs}, \mathrm{CO}$, and NO (Colville et al.; 2001). Alternatively, battery operated vehicles, alcohol fuels, and liquid petroleum gas (LPG), compressed natural gas (CNG) can be introduced in Nigeria as alternatives to diesel and petrol. Furthermore, Exhaust Gas Recirculation (EGR) can be implemented to reduce the emissions of oxides and peak engine temperatures in petrolpowered vehicles (Wei et al., 2012). 
C. Change Petroleum Fuel Vehicles to Fuel Cell Technology

Fuel cell technology entails conversion of chemical energy into electrical energy directly (Varga, 2007). The fact that this technology utilizes hydrogen to generate electricity that in turn, is used to power vehicles is a form of green energy that significantly reduces transport-related emissions (Sharaf and Orhan, 2014).

\section{Reduce Distance Driven and Time on the Road}

According to Ehmke et al., (2016), driving fewer kilometers reduces the number of emission gasses emitted by the vehicle. This scenario is like spending less time on roads. Gajanand and Narendran (2013) state that load carried, state of the road, speed, and other parameters of cars apart from a distance covered affects the emission of pollutants as well as the fuel consumption of the car.

\section{E. Keeping Cars in Top Condition}

Routine maintenance of the car keep it in good condition hence optimal efficiency in terms of fuel consumption and emission of gases. Car drivers can ensure their cars are performing at optimal efficiency by keeping car tires properly inflated; reducing the weight in cars; removing the roof rack and steady driving on the road.

\section{F. Walk or Bike}

According to Amanda (2018), major cities have started to experiment with the use of bikes share program, which is equivalent to car cooperatives. Some countries such as China have adopted e-bikes as an alternative for fuel vehicles (Ji et al., 2012).

In Nigeria, the design of the road does not give room for pedestrian walking, and there are no dedicated lanes for bikes like the United Kingdom and most developed countries. This is a big challenge in the fight to reduce road transport emissions in Nigeria.

\section{FINDINGS AND DISCUSSION}

The findings of this study based on the review of accumulated emissions by subgroup within the Nigerian transportation industry (Table 1.0) shows that road transport system emitted the highest amount of this subgroup with $34322.5 \mathrm{Gg}$ CO2-eq $(95.3 \%)$ based on the entire 36022.3 $\mathrm{Gg}$ CO2-eq with vehicles accounting for $63.8 \%$ of this activities area. This is followed by local waterborne transportation which accounts for $1518.2 \mathrm{Gg} \mathrm{CO} 2-\mathrm{eq}$ (4.2\%), local aviation which accounts for $99.1 \mathrm{Gg} \mathrm{CO} 2$-eq $(0.3 \%)$ and railway transport which accounts for $82.5 \mathrm{Gg}$ $\mathrm{CO} 2$-eq $(0.2 \%)$. CO2 with approximately $35240 \mathrm{Gg} \mathrm{CO} 2$-eq accounting for $97.8 \%$ of the entire emissions of approximately $36022 \mathrm{Gg} \mathrm{CO} 2$-eq. $\mathrm{CH} 4$ accounted for $0.9 \%$ and $\mathrm{N} 2 \mathrm{O} 1.3 \%$ with emissions of approximately $308.57 \mathrm{Gg}$ $\mathrm{CO} 2$-eq and $474.21 \mathrm{Gg} \mathrm{CO} 2$-eq respectively.

Findings from the study also show that factors such as lack of good roads, poor vehicle maintenance, lack of technology, inadequate transport researches among others are some of the reasons why Nigeria and other developing countries are still struggling to minimize transport emissions. Electrification of public vehicles, changing petroleum-driven engines to fuel cell technology, reducing time spent on the road and distances driven, and keeping cars in top condition are some of the suggested ways to reduce emissions in Nigeria.

\section{RECOMMENDATIONS}

Considering the findings and their consequent conclusion and implications, the following recommendations were made as a way towards reducing vehicular emissions in Nigeria.

- Design guidelines: Policymakers and urban planners in the built environment ought to formulate suitable management and design solutions that will promote the sustainability of the environment.

- A more walkable city: A metropolitan transportation system, as well as the urban planning team, should consider the remodeling from vehicles to mass transit, bicycles, and pedestrians. This move will help in the reduction of congestion and air pollution.

- Culture and Education: People's psychological reorientation should be realized to facilitate suitable practices that support the management of the environment. Besides, public awareness campaigns can be crucial in curbing unfavorable environmental practices.

- Infrastructure investment: Increase the carrying capacity of the environment. Extensive measures to expand and restore the infrastructure in metropolitan areas should be seriously taken towards the reduction of pressure and congestion on the road.

- Public transport: Improve public transport efficiency and services in Nigeria major cities: public transport not only saves travel time but also reduces greenhouse gases and local air pollutant emissions.

- Construct more roads with more lanes to ease congestion in Nigeria major cities.

- Ensure that public roads are regularly maintained and upgraded in Nigeria.

- Regular cars maintenance to reduce vehicular emissions on the roads in Nigeria.

\section{REFERENCES}

1. Adedeji, I. (2014). Traffic Demands and Delays on Lagos -Ikorodu Road in Nigeria. Journal of Environmental Issues and Agriculture in Developing Countries, 6(1), 2141-2731.

2. Agbigbe, W. A. (2016). The Impact of Transportation Infrastructure on Nigeria's Economic Development. ProQuest Dissertations and Theses. Walden University.

3. Agbonkhese, O., Yisa, G., Agbonkhese, E., Akanbi, D., Aka, E., and Mondigha, E (2013). Road Traffic Accidents in Nigeria: Causes and Preventive Measures. Civil and Environmental Research, 3(13), Pages 90-100.

4. Akinola, A., Suleiman, A., Adeleye, A., Akinluyi, F., and Dauda, A (2014) Air pollution and climate change in Lagos, Nigeria: Needs for proactive approaches to Risk management and adaptation. American Journal of Environmental Sciences 10 (4): 412-423.

5. Amanda McMillan. (2018). Global Warming 101 Definition, Facts, Causes and Effects of Global Warming | NRDC.org. 
6. Colvile, R. N., Hutchinson, E. J., Mindell, J. S., \& Warren, R. F. (2001). The transport sector as a source of air pollution. Atmospheric Environment.

7. Daniel, S. and Deborah, S. (2002) Transportation in Developing Countries: An Overview of Greenhouse Gas Reduction Strategies. Prepared for the Pew Centre on Global Climate Change. University of California, Davis.

8. David, G., Osca, M., Samantha, M., and Niruthavignesh, S (2016). New solutions to air pollution challenges in the UK- Grantham LFSP paper. Produced by the London Forum for Science and Policy; published by the Grantham Institute

9. Ehmke, J. F., Campbell, A. M., \& Thomas, B. W. (2016). Data-driven approaches for emissions-minimized paths in urban areas. Computers and Operations Research, 67, Pages 34-47.

10. European Commission. (2011). Roadmap to a Single European Transport Area - Towards a competitive and resource efficient transport system. White Paper on European transport policy. COM (2011) 144 final (pp. 1-31). Office for Official Publications of the European Union.

11. First Biennial Update Report (BUR1) of the Federal Republic of Nigeria Under the United Nations Framework Convention on climate change (UNFCCC) March (2018).

12. Gajanand, M. S., \& Narendran, T. T. (2013). Green route planning to reduce the environmental impact of distribution. International Journal of Logistics Research and Applications, 16(5), 410-432.

13. Igwe, C.N., Oyelola, O.T., Ajiboshin I.O., Raheem S., (2013) A Review: Nigeria's Transportation System and the Place of Entrepreneurs. Journal of Sustainable Development Studies ISSN 2201-4268 Volume 3, Number 2, 2013. Pages 168-180.

14. International Energy Agency (2016). CO2 emissions from fuel combustion by sector in 2014, in $\mathrm{CO} 2$ Emissions from Fuel Combustion, IEA, 2016. In CO2 Highlights 2016.

15. Ji, S., Cherry, C. R., Bechle, M. J., Wu, Y., \& Marshall, J. D. (2012). Electric vehicles in China: Emissions and health impacts. Environmental Science and Technology, 46(4), 2018-2024.

16. Kim, K. H., Kabir, E., \& Kabir, S. (2015, January 1). A review on the human health impact of airborne particulate matter. Environment International. Elsevier Ltd.

17. Mihaela, C., Alina, M. and Nicuta, R. (2018) Environmental Impat of Road Transport Traffic. A case Study for County of Iasi Road Network. Procedia Engineering. Volume 181, pages 123-130.

18. Okigbo, N. (2012). Causes of Highway Failures in Nigeria. International Journal of Engineering Science and Technology (IJEST), 4(11), 4695-4703.

19. Orisaleye, J., Ope, A., Busari, O., and Adefuye, O (2018). Environmental and Health Effects of Industrial and Vehicular emissions in Lagos, Nigeria. Annals of Faculty of Engineering Hunedoara - International of Engineering. Tome XVI (2018).

20. Potter, S., \& Skinner, M. J. (2000). On transport integration: A contribution to better understanding. Futures, 32(3-4), Pages 275-287.

21. Santos, G. (2017). Road transport and CO2 emissions: What are the challenges? Transport Policy, 59, 71-74.

22. Sharaf, O. Z., and Orhan, M. F. (2014). An overview of fuel cell technology: Fundamentals and applications. Renewable and Sustainable Energy Reviews.

23. Transport and Environment Annual Reports (2012).

24. Varga, Á. (2007). Introduction to Fuel Cell Technology. In Fuel Cell Electronics Packaging (pp. 1-32). Springer US.
25. Wang, C., Quddus, M., and Ison, S. G. (2009). Impact of traffic congestion on road accidents: A spatial analysis of the M25 motorway in England. Accident Analysis and Prevention, 41(4), 798-808.

26. Wei, H., Zhu, T., Shu, G., Tan, L., \& Wang, Y. (2012). Gasoline engine exhaust gas recirculation - A review. Applied Energy. Elsevier Ltd.

27. World Health Organisation (WHO), Krzyzanowski, M., Kuna-Dibbert, B., and Schneider, J. (2005) Health effects of transport-related air pollution. ... (p. 59).

28. World Health Organization (WHO) Reports on Emissions.

\section{AUTHORS PROFILE}

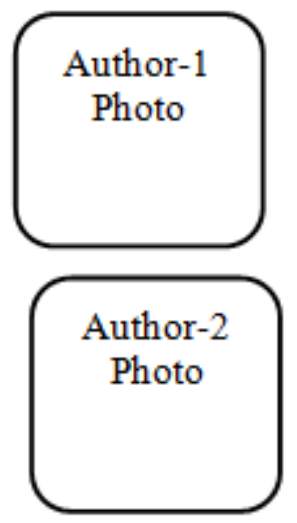

Augustine Odogun is a PhD student in the Faculty of Science and Engineering at the University of Wolverhampton, United Kingdom. His research work is Developing a Safety Framework for the Transportation of Petroleum Products: A case study of the

Nigerian Oil and Gas industry.

Dr Panos Georgakis is a senior lecturer in the Faculty of Science and Engineering at the University of Wolverhampton, United Kingdom 